\title{
The Clausewitzian and Heuristic Evolution of the ANC's Armed Struggle: A Dependent Pillar of the South African Revolution ${ }^{1}$
}

\section{Gcwelumusa Chrysostomus Khwela}

\begin{abstract}
The paper tries to address the armed struggle as one of the pillars of the South African revolution, especially its adoption, together with the underground component, after all other avenues had been restricted. The argument emphasises the centrality of the political struggle, particularly the other two pillars of the revolution: mass mobilisation and international isolation of the racist government. The armed struggle and the underground are regarded as extension pillars necessitated by objective conditions, which demanded the ANC to reveal its existence through other means, since it was banned as a legal political force internally. This argument is stressed by looking at the nature of the adoption of the armed struggle, its heuristic evolution, from armed propaganda until the late 1970s, and particularly the 1980 s, when there was more focus on revolutionary people's war, its protracted nature, the role and structure of the people's army, and the armed seizure of political power through insurrection. Thereafter the paper discusses the debate that emerged with the realisation that there were possibilities of a negotiated settlement, the subsequent contest between absolute and relative victories, and the preparation of the cadres for integration into the new SANDF. The paper concludes with the need to revisit the Integration Process, especially the need to re-orient the uniformed members' political attitudes towards a common cause.
\end{abstract}

(This paper is dedicated to the Commander of the Luthuli Detachment of Umkhonto We Sizwe, Basil February - alias Paul Peterson - the Lion of the West Coast, in Saldanha, who fell in Zimbabwe - then Rhodesia - in the joint MK-ZIPRA Wankie and Sipolilo Campaigns of 1967-8). 
"No people can accept slavery for ever. We have reached a stage where we have taken a decision to liberate ourselves, and no force on earth can stop us from attaining that objective."2

\section{Introduction}

After having utilised all forms of struggle to appeal to the racist South African government to heed the call for a non-racial and democratic dispensation, and after all the national liberation movements have been banned following the Sharpeville Massacre, it became clear for the African National Congress (ANC) that the only way of having its voice heard was the adoption of an underground dimension which will facilitate the armed struggle. The approach was to build Umkhonto we Sizwe (MK), which was to be the armed wing of the Congress Movement that was led by the ANC and including the South African Congress of Trade Unions (SACTU) and the South African Communist Party (SACP). Ever since the Bambata Rebellion of 1906, which was the last effort of the Wars of Resistance, the struggle for liberation had always been in the form of sending delegations to the colonial masters in the United Kingdom, as well as consistent mass action. Mass action included demonstrations, picketing, passive resistance, and the most successful of all, total defiance, which led to the anti-pass and other campaigns of the 1950s and the early 1960 s, which resulted in the outlawing of the national liberation movements.

This paper tries to address the armed struggle, from the perspective of Umkhonto We Sizwe, as one of the pillars of the South African revolution, without necessarily drawing on the history or the experiences of those leaders who decided to adopt the armed struggle as a weapon of transformation. It is quite a rosy discourse on the armed struggle since the intention is not to scrutinise its strategic, operational and tactical successes and flaws but as a component of the whole political struggle of the ANC. The emphasis, therefore, is on the centrality of the political struggle, and that the armed struggle and the underground were regarded as extension pillars, necessitated by objective conditions, which demanded the ANC to reveal its existence through other means, since it was banned as a legal political force internally. However, as a result of the intransigence of the apartheid government over the years, the armed struggle developed to become the central pillar of the South African revolution. The ANC began to stress the centrality of revolutionary people's war, its protracted nature, the role and structure of the people's army, and the armed seizure of political power through insurrection. Finally, focus began to be on the willingness to negotiate on the part of the apartheid government, as domestic and global pressure mounted, the apartheid economy deteriorated, the racist government's failure to govern, and the imminent threat of extending the war from the townships into the white areas. The national liberation movement realised that negotiations were a means of obstructing the revolutionary

Modise, Joe. (1983). "We Have Taken a Decision to Liberate Ourselves." (An Interview). SECHABA: Official Organ of the African National Congress South Africa. Oct 1983. p 14. 
seizure of power, which could have resulted in absolute victories for the oppressed majority. Nonetheless, the move to negotiate was sanctioned for the well-being of the country and its people, even though it was evident that the absolute victories envisaged would be compromised. As one culmination of the negotiation process, was the integration of Umkhonto we Sizwe into the new South African National Defence Force (SANDF), along with all other armed forces that prevailed in the South African political landscape, which was a successful endeavour but still requiring an exceptional political re-orientation programme.

\section{Armed Propaganda: The Armed Struggle as a Pillar of the National Democratic Revolution}

Since 1912 when the ANC was formed, the struggle for liberation was always focussed on addressing the fundamental political question, the issue of political power. The Union of South Africa of 1910 and the ascendancy of the apartheid National Party, in 1948, which led to the declaration of South Africa as a republic, did not consider, in fact ignored, the aspirations of the majority of the country, the African people. The struggle of the ANC, therefore, was aimed at addressing this question, that power belonged to the people, and not to a certain sector of the population by virtue of its racial disposition.

"The formation of the African National Congress, on January 8, 1912, was an expression of the future of people's power won through protracted and bitter struggles against the combined Boer and British colonial enslavement. The ANC was, and remains to this day, the organised political representative and fighting force for the attainment of democratic and revolutionary change in our society." 3

This focus was ultimately covered in the Freedom Charter, which was adopted by the Congress of the People in Kliptown, in 1955. The Freedom Charter thus became the political blueprint of the ANC and its allies, in the Congress Movement, as well as the essence of the national democratic revolution. The Freedom Charter thus distinguished the Congress Movement from all other formations and fraternities that prevailed in the South African political landscape.

\section{The Congress Movement: From Protest to Challenge}

Amongst the allies in the Congress Movement were the Coloured People's Congress, the South African Indian Congress, the South African Congress of Democrats, and most importantly the structures of the working class movement, the South African Congress of Trade Unions (SACTU) and the South African Communist Party (SACP). The former allied congresses, besides the working class movement, reflected the racial distribution of South African society, and all of them

Statement by the National Executive Committee of the African National Congress on the Occasion of the $70^{\text {th }}$ Anniversary of the Foundation of the ANC, Jan 8, 1982. (1982). SECHABA: Official Organ of the African National Congress South Africa. Feb 1982. p 5 . 
finally united under the banner of the ANC. The working class movement, on the other hand, had objectives beyond the national democratic revolution (the goals of which were conceived in the Freedom Charter), as it pursued the further goal of building socialism in South Africa, after the objectives of the national democratic revolution have been fully realised. According to the Two-Stage theory of the working class movement, South Africa was not a classical colony as other colonies in the African continent, but was conceptualised as a Colonialism of a Special Type, wherein two nations, the coloniser and the colonised, were found within the same boundaries. According to the SACP's definition of "Colonialism of a Special Type" in its 1962 Programme, The Road to South African Freedom:

"South Africa is not a colony but an independent state. Yet masses of our people enjoy neither independence nor freedom. The conceding of independence to South Africa by Britain, in 1910, was not a victory over the forces of colonialism and imperialism. It was designed in the interests of imperialism. Power was transferred not into the hands of the masses of the people of South Africa, but into the hands of the white minority alone. The evils of colonialism, in so far as the non-white majority was concerned, were perpetuated and reinforced. A new type of colonialism was developed, in which th (sic) oppressing white nation occupied the same territory as the oppressed people themselves and lived side by side with them."

The solution to this colonialism was the national democratic revolution, with the black working class, as the most oppressed and exploited, leading the process, to accordingly ensure the accomplishment of the objectives of the Freedom Charter.

The attainment of the objectives of the national democratic revolution was programmed along two main pillars: united mass action and the international isolation of the racist government. United mass action involved primarily defiance campaigns, such as boycotts, stay-aways, pass burning campaigns, contempt of discriminatory legislation, and so on. This pillar of struggle became the central, and indeed effective, means through which the apartheid government was challenged within the confines of legality, as the Congress Movement was groomed in previous protest actions such as delegating, picketing, demonstrating, and passive resistance, amongst others. The success of united mass action, therefore, relied mainly on politically educating and organising the masses, as defiance campaigns were envisaged to be, and really became, a shift from protest to challenge. Complementing the strategy of united mass action was the effort of exposing the atrocities of the apartheid government internationally, so as to solicit its isolation from the global community of states and simultaneously provide a platform and assistance to the struggles of the oppressed masses of South Africa. Both these

Quoted in Cabesa, Quadro. (1986). "From Ungovernability to Revolution: Some Burning Issues of Strategy and Tactics." African Communist. No. 104. First Quarter 1986. p 28. 
pillars of the struggle were regarded as foremost in the enterprise to finally destroy the apartheid system.

\section{The Adoption of the Armed Struggle and the Creation of the Underground Structures}

Mass struggles became the order of the day all over the country in the late 1950 s into the early 1960s. The National Party government responded to these activities by force and these resulted in mass arrests and detentions, culminating in individuals being banned and others involved in a string of treason trials. Ultimately, after an anti-pass campaign organised by the Pan Africanist Congress (PAC) resulted in a massacre in Sharpeville in March 1960, all the national liberation movements were outlawed. All the activities of the Congress Movement, particularly the ANC and the SACP, were ostracised and the leadership was sent to prison. Accordingly, it became apparent that in order to be able to continue existing, the movement had to go underground as well as to exile and begin waging armed operations against the government. Even when MK was formed in December 1961, the objective was to make the apartheid government aware that it could not silence the people's desire for freedom, except by accepting the creation of a non-racial and democratic state.

What is important to note is that belonging to the ANC or its allies was a treasonable offence at that time, and as such the underground structures and the armed struggle were the only responses to the oppressive measures that were orchestrated by the apartheid government. It was not the intention of the Congress leadership to resort to arms, but there were no other options to prove to the masses and to the oppressive state that the movement was not silenced. Hence the ANC and the SACP, under the leadership of Nelson Mandela and Joe Slovo respectively, decided to resort to the armed struggle as a tool of pursuing the political struggle by other means - means that the racist government would understand well. According to the statement of the ANC's National Executive Committee in 1982, the ANC was

"...better placed to move in on the enemy because today we have a popular army, Umkhonto we Sizwe, capable of speaking to the enemy in the language he understands best." 5

Moreover, the masses, who had sacrificed their livelihood, families and self-respect, could not be disappointed by the leadership, which should have anticipated the harsh responses of the apartheid government. Therefore, the armed struggle became also a means to prove to the masses that the ANC was alive and kicking, and that it will ultimately overcome the apartheid system. For the leadership of the ANC, the armed struggle became nothing more than an armed propaganda campaign, involving mainly sabotage and guerrilla warfare. This was

Statement by the National Executive Committee of the African National Congress on the Occasion of the $70^{\text {th }}$ Anniversary of the Foundation of the ANC, Jan 8, 1982. Op cit. p 6 . 
confirmed by the 1965 statement of the Central Committee of the South African Communist Party which maintained that:

"Indeed, it should rather be said that without constant efforts to arouse the resistance and patriotic spirit of the people, activities of a purely military character will become isolated from the people and bound therefore to fail. The real advantage of the liberation forces over the planes, armoured cars and other superior equipment of the enemy, is the support of the masses. This is our decisive weapon." 6

Underground structures and methods were therefore essential for sabotage and guerrilla warfare to succeed, and cadres were sent to countries abroad to train and equip themselves in order to be able to master these skills. ${ }^{7}$

\section{The Political Focus of Guerrilla Warfare Training}

Most of the training for the armed struggle was done in the Eastern Bloc countries, especially in the former Soviet Union, which was willing to assist national liberation movements, and the communist movement in general, with armaments and military training. The socialist states in the Eastern Bloc and in Cuba, based their assistance on the principle of "Proletarian Internationalism" and the conviction that the national liberation movements were part of the world revolutionary process against imperialism. Moreover, in the South African context, the national liberation movement was allied to a Marxist-Leninist party, the SACP, which could further the national liberation struggle towards socialism. Other countries that provided military training included the member-states of the Non-aligned Movement, particularly Yugoslavia, the liberated countries of the Organisation of African Unity, which included, inter alia, Algeria, Tanzania, Zambia, and Egypt.

Training included the art of guerrilla warfare, sabotage, intelligence gathering and processing, but most importantly, the art of political organisation, mobilisation, agitation, and leadership. Although the art of warfare was central to all the training that was provided, the ANC and the SACP ascertained that all the cadres had proper political understanding of the objectives envisaged. Every combatant was groomed to be a political ambassador of the ANC in whatever country he or she was sent to obtain further military training. Therefore, the underlying focus of all training was stressed on the political dimension. The argument maintained that

"Much of our strategy has been premised on the fact that even the initial states of armed struggle could not (in the case of South Africa) depend upon those kind of (rear base) facilities. In general, the training, arming,

Quoted in Migwe, Khumalo. (1982). "Further Contribution on the Arming of the Masses." African Communist. No. 89. Second Quarter 1982. p 82.

7 Kasrils, Ronnie. (1988). "The Revolutionary Army: A Discussion Article." SECHABA: Official Organ of the African National Congress South Africa. Sep 1988. p 7. 
infiltration and replenishment of relatively large armed units operating in proximity to friendly borders (which was the pattern of the early phases of almost every single armed struggle in Africa) has never been the basis of our strategy. We have concentrated on internal growth deep inside the country around a core of trained revolutionary politico-military cadres in both rural and urban areas. We have deliberately avoided the pattern of using adjacent territory to hit close to the border and to run back. The second point of emphasis is the special role in our conditions of urban guerrilla warfare and sabotage. This needs to be noted particularly in relation to the existence in our country of a relatively advanced capitalist economy and a working class which is the most important force in our revolutionary process. But above all, our starting point has always been on the political struggle, political organisation and underground leadership." $" 8$

From the above, it is obvious that cadres of MK were not just mere soldiers, but were soldiers with a political mission: to destroy the apartheid regime and to establish a non-racial and democratic South Africa, as visualised in the Freedom Charter. Therefore, MK was the champion of the two pillars, the underground structures and the armed struggle, of the national democratic revolution.

\section{People's War and Insurrection: The Centrality of the Armed Struggle}

Despite of the efforts of the ANC in advancing the political struggle through armed propaganda and the dimension of exerting international pressure on the apartheid government, the latter remained adamant in pursuing its policies and became more repressive than ever before. Nevertheless, the struggles for liberation in the developing world continued to gain momentum in the early and mid-1970s, in particular the successes of the Vietcong in Vietnam, the PAIGC in Guinea-Bissau and Cape Verde, the MPLA in Angola, as well as FRELIMO in Mozambique. These successes, along with the protracted armed actions of the ANC, animated the desire for liberation amongst the South African masses. The pillar of united mass action was revitalised with the workers' strikes of 1973 in Durban and, most significantly, the June 16, 1976, uprisings in Soweto, which spread like wild fire throughout the urban and certain semi-rural sectors of the country. The apartheid government responded with more repression, killing hundreds of school kids and turning the country into a police state.

"One after the other, patriots....were to die in police custody, form attack carried out by the bantustan administrations, from repressive measures carried out by the Pretoria regime, in ambushes laid by counter- 
revolutionaries in Angola and yet others, not necessarily members of the ANC, but opponents of apartheid...in mysterious circumstances."9

The international community responded with indignation, imposing economic and other sanctions against the apartheid government, with the latter, nevertheless, determined to pursue its own racist agenda. A lot of the students that were involved in the 1976 mass uprisings left the country to join the national liberation movement, after realising that the only language that the racist government understood was violence, and that the armed struggle was the only solution under those circumstances.

\section{"Total Onslaught" and the Crisis of the Apartheid Leviathan}

With the events of 1976 and its aftermath, B.J. Vorster's police state was overthrown by the South African Defence Force (SADF), under the leadership of P.W. Botha and the generals. The SADF-led government introduced new measures to counter the activities of the national liberation movement, which were branded as a "Total Onslaught", said to be driven by the world communist movement. ${ }^{10}$ The ANC was described as a tool for communist domination in South Africa, and the liberated states of Southern Africa as springboards used by the Soviet Union in order to overthrow a Western-oriented "legitimate" government. The effort of the Botha government was to legitimise its adverse repressive measures, as well as its acts of destabilisation in the Southern African region, in the eyes of the West and within its white minority electorate. The whole country was turned into a military garrison and all the undertakings were towards defending the Apartheid State from the hammer of the armed struggle and the anvil of mass action, as well as from the pressures that were meted out by the international community. It was obvious that the apartheid leviathan was facing crisis within its ranks, as it became more and more isolated from the international community, and its white minority electorate began to question the prudence of the apartheid project. ${ }^{11}$

“As Dr Hermann Giliomee of Stellenbosch University puts it: 'Mr Botha can never lead a united Afrikanerdom again; ethnic trust, once forfeited can never be restored.' Added to this is the fact that apartheid has collapsed as an ideology and thus as a binding force for Afrikaner nationalism ... so, in addition to being split and divided ethnically,

ANC National Executive Committee. (1986). “The Eyes of Our People are Focused on This Conference: Political Report of the National Executive Committee to the National Consultative Conference, June 1985. SECHABA: Official Organ of the African National Congress South Africa. Feb 1986. p 3. 
Afrikaner nationalism has also been plunged into an ideological vacuum with no new articles to knit together."12

The response of the racist government was to develop a fortified state, canvassing support amongst other international pariahs like Israel, Taiwan and Chile, and introducing more repressive measures against the growing mass democratic movement within the country. The frontline states became targets of the apartheid war machinery, as acts of destabilisation and sabotage became persistent with the creation and sustenance of the rebel movements. The situation was further aggravated by the victory of the ZANU-PF against the Smith regime in Rhodesia, and the establishment of a majority government in a new Zimbabwe, which further revived the spirit of united mass action within South Africa. People became optimistic that the downfall of the apartheid government was inevitable through a consistent revolutionary programme, which combined the pillar of united mass action with an effective armed struggle. The people could not believe otherwise, as a powerful white government was forcefully overthrown, under the apartheid government's own nose, in a closely neighbouring state. For the ANC, the revolutionary conditions were more favourable than ever before, as the masses were prepared to become part and parcel of the armed seizure of political power. ${ }^{13}$

\section{People's Army, People's War and People's Power}

With the apartheid government consolidating its hold on power by establishing a martial state and getting more and more intolerant of the oppressed majority's demands for a new dispensation, the ANC became more convinced that the only solution to the South African problem was through the armed seizure of power.

At its beginning, the armed struggle was understood in our liberation movement as a pressure tactic. Its pioneers saw it as having four forms (sabotage, guerrilla warfare, terrorism and open revolution) whose effectiveness as a language of communication with the enemy differed. ...(A)rmed struggle as a tactic has undergone a two-stage evolution in its...history. Today armed struggle is in the historical era where it is warfare by the oppressed led by their liberation movement. It is not the only form of our people's struggle for the genuine decolonisation of their country, but it is the decisive one."14

The programme was to transform MK into being the nucleus of a People's Army that would wage a People's War against the apartheid government, culminating in the seizure of political power by the masses through insurrection.

Allister Sparks quoted in Mashinini, Alex. Ibid. p 18.

ANC National Executive Committee. Op cit. pp 4 - 5.

Mandla, Cassius. (1986). "Umkhonto We Sizwe: Let Us Move to an All-out War." SECHABA: Official Organ of the African National Congress South Africa. Nov 1986. pp $26-27$. (Own annexations in bold). 
This new programme of action was eclectically developed from the various experiences of revolutionary warfare, particularly the experiences of the People's War in Vietnam, against the French and the United States, which were creatively applied to the South African situation. The art of People's War could not be applied without the fundamental foundation of a revolutionary attitude amongst the masses, which had to be nurtured and channelled accordingly for the realisation of a revolutionary situation.

"...(A) successful revolution is dependent on subjective factors - the mood of the masses, their confidence in the revolutionary movement, and its organisational ability to lead them out of the current impasse to the seizure of power. ... The subjective factor is organisation. It is the existence of a revolutionary party or movement which is capable of providing the correct strategic and tactical guidance, having created the forces and means to carry out the tasks of the struggle. This includes also the political and military readiness of the advanced masses, who become part of the revolutionary army." 15

How was the revolutionary attitude to be nurtured and channelled, and how was the revolutionary situation to be attained? The ANC developed a programme action that declared the 1980s as a "Decade of Liberation", which implied that every year would be given a Theme, which will prescribe the courses of action to be taken in the build up towards a revolutionary situation. ${ }^{16}$ This in turn would ensure that the ANC seizes the initiative from the apartheid regime, to wit, that instead of responding to the atrocities of the racist government, the latter will be compelled to respond to the activities of the liberation movement. What was fundamental to the success of this programme was the role of the underground structures in grooming and directing the actions of the masses within the country so that they could be co-ordinated with the ANC's predetermined programme. The subsequent component would be the establishment of a countrywide mass democratic movement to co-ordinate the progress of mass action within all the organisations, associations and fraternities that subscribed to the objectives of the national democratic revolution, as envisaged in the Freedom Charter. This insinuated that all these organisations had to be united behind a common programme of action that will ensure that the masses in the country were keeping the pace with the leading structures of the national liberation movement, which were mainly based in exile, in the underground, and in prison. Last but not least, was a determined effort towards deepening the isolation of the apartheid government and simultaneously ensuring that the national democratic revolution received as much

Kasrils, Ronnie. Op cit. p 4.

See the 1979 - 1991 publications of SECHABA: Official Organ of the African National Congress South Africa. 
moral, material and financial support as possible from the international community. ${ }^{17}$

Most importantly, was the central role that MK, as the nucleus of the People's Army, had to play in ensuring that the armed struggle became pivotal to the success of the national democratic revolution. Although armed propaganda became the most significant element of this programme of action, particularly the special operations against strategic targets inside the country, the primary focus of training and infiltration of cadres was the development of a second layer of the People's Army, the Combat Units, which were labelled the Revolutionary Armed People (RAP), and the development of a third layer composed of apartheid renegades recruited from the SADF and the Police. ${ }^{18}$ The RAP were drawn and selected by the underground structures from the internal structures of the ANC and from the mass democratic movement.

"Certainly, in South Africa, where cadres of Umkhonto We Sizwe can go inside the country and carry out combat operations like the assaults on Sasol and Voortrekkerhoogte military base, it is quite possible to create temporary training bases in some houses or mountains (even if for the duration of a weekend) and train small groups of carefully selected people from the factory floor, village, migrant workers' hostel, university or high school. In this way the primary task of many MK cadres would be to multiply themselves among the people inside the country rather than all of them doing the actual fighting at this stage."19

The intention was to organise the RAP into cells that would fulfil two main objectives: the defence of the people in the townships; and for the ultimate goal of extending the revolutionary war from the townships into the white areas. The role of defending the people would be accompanied by the establishment of alternative structures of governance, which insinuated that the apartheid government would not be able to govern those areas that were controlled by the national liberation movement. This in turn would make the country ungovernable and apartheid unworkable, as dual power would be prevailing in the country. ${ }^{20}$ In those areas where the organs of people's power had been established, no-go areas would be created for the apartheid state machinery, particularly the defence force and the police.

Tambo, O.R. (1986). “Attack! Advance! Give the Enemy No Quarter! January $8^{\text {th }}$ Message of the National Executive Committee of the African National Congress." SECHABA: Official Organ of the African National Congress South Africa. Mar 1986. p 7.

Shombela, Mafosi. (1986). "Our armed Offensive: Military Strategy in South Africa." SECHABA: Official Organ of the African National Congress South Africa. Mar 1986. p 19.

Migwe, Khumalo. Op cit. p 80.

Tambo, O.R. Op cit. pp 6-7. 
"The people's combat activities must have the aim to take from the enemy, little by little, the enemy's ruling power: in this way it becomes possible to talk of certain areas as liberated areas, that is, at first from the political point of view. A situation is created where the enemy's administrative organs are completely destroyed... Certainly, the liberated zones may not take the classical form of defended territories in the developed stage of guerrilla warfare, but it may be quite possible to talk of politically liberated Soweto, New Brighton, KwaMashu, Mondlo, Gugulethu, etc. from the point of view that it is no longer the enemy that has power in these areas but the people. This will be a very important stage in the process of the mobilisation of the masses." 21

These no-go areas, controlled and administrated by the structures of the national liberation movement, were to be developed into mass revolutionary bases for the launching of a People's War. ${ }^{22}$

As soon as the apartheid government began to respond to the ANC's programme of action, it began to loose the initiative, and gradually its activities became predictable on a daily basis. Each and every day, planned actions were met with an anticipated response, like the development of the National Security Management System, which was saliently a reactive structure to the ANC's design of the Street, Area and Regional Committees, which were the incipient Organs of People's Power.

"In the course of our mass offensive, we have, from time to time and with increased frequency, created the situation in various localities such that the democratic forces challenged the apart-heid (sic) authorities for control of these areas emerging as the alternative power. With regard to the perspective of people's war, this means that we forged the conditions for us to transform these areas into mass revolutionary bases from which Umkhonto we Sizwe must grow as an army of the people. We must all take it as a priority task to build up the popular armed forces, to transform the armed actions we have thus far carried out into a people's war, by helping to root Umkhonto we Sizwe firmly among the people and actively drawing the masses into the prosecution of a people's war." 23

An actual Total Onslaught was beginning to crush apartheid, as it sunk deeper and deeper into crisis, and trying desperately to find a racist-orientated dispensation to preserve white minority rule, at the same time trying to co-opt certain sectors of the oppressed majority into its futile schemes. The objective and

Migwe, Khumalo. Op cit. p 85 .

Tambo, O.R. Op cit. p 7.

Tambo, O.R. (1985). “Render South Africa Ungovernable: President O.R. Tambo's Message Delivered in Lusaka on Jan 8, 1985." SECHABA: Official Organ of the African National Congress South Africa. Mar 1985. p 12. 
subjective elements of a revolutionary situation were slowly unfolding, with the underground structures and MK constantly building the layers of the People's Army that were being processed for People's War. The focus of all the efforts was to prepare on all fronts for the dawning of People's War and the seizure of political power through insurrection.

The tasks of the People's Army in this phase of the struggle was to duplicate itself into multitudes of forces to confront the racist forces in the townships, to defend the gains of the revolution, and to extend the war to the enemy in the white areas, the suburbs, the industrial centres, and the central business districts. In the words of ANC President O.R. Tambo, "The charge we give Umkhonto we Sizwe and to the masses of our people is: attack, advance, give the enemy no quarter - an eye for an eye, a tooth for a tooth!" ${ }^{24}$ The intention was to make the white areas to shake from their comfort zones, to experience what the whole country was going through, and to involve the White community in the fight against apartheid.

"Our strategy is to take the present war into white areas, and not to share power with any apartheid structure... The immediate practical objective in extending the people's war into the white areas is to fight against the existence of the municipal councils, who occupy in the apartheid structure the same position as the community councils which were occupying the townships. ...Our attempts to consolidate people's power in the Black townships should never be misunderstood to imply that this is the endresult of our strategy. We are not fighting just to liberate and control Soweto, Gugulethu or Lamontville. Our final intention is to form a people's government in the whole country... White South Africa cannot be at peace while the Black townships are in flames. The comfort and security the Whites enjoy in their suburbs are the direct result of our oppression and exploitation. This then is another dimension of our people's war: the creation of people's communes to include White democrats and all those Whites who do not want to be associated with the obnoxious apartheid system."25

This strategy was mostly influenced by the responses of certain sectors of the White community, particularly the business and religious sectors, to the atrocities committed by the SADF in the townships and in the neighbouring states. Moreover, the number of conscientious objectors to being part of the SADF increased massively in the period of the 1980 s, as young white males, especially in

Tambo, O.R. (1986). "Attack! Advance! Give the Enemy No Quarter! January $8^{\text {th }}$ Message of the National Executive Committee of the African National Congress." SECHABA: Official Organ of the African National Congress South Africa. Mar 1986. p 7.

Majola, Sisa. (1986). "The Beginnings of People's Power: Discussion of the Theory of State and Revolution in South Africa." African Communist. No. 106. Third Quarter 1986. p 62. 
certain tertiary institutions, became conscious of the negative direction that the country was following as a result of futile apartheid policies. ${ }^{26}$ It thus became imperative to ensure that members of the white community, who did not appreciate the policies of apartheid, were recruited into the mass democratic movement, and those who were prepared to join the ranks of the revolutionary movement be politically and militarily trained to become part of the People's Army or even to penetrate and infiltrate the security forces of the government as intelligence collectors, false disseminators, agitators and saboteurs.

"The fact that many White conscripts in the SADF are disaffected creates possibilities of at least neutralising significant sections of the White soldiers and possibly winning some elements over to our side, at the decisive moment. .... We have to move away from simply encouraging Whites to refuse to serve in the SADF, to getting them actively involved in the SADF for purposes of clandestinely organising and agitating from within, no matter how difficult such a task may appear to be." 27

With the success of these efforts of the ANC-led revolutionary offensive, and the other external factors that had a direct impact on the South African political situation, the apartheid government was finally forced to remove the bellicose and intransigent elements within its ranks and to heed the advice of the religious, business and international communities to opt for a negotiated settlement.

\section{Negotiations: Absolute Victories versus Relative Victories}

The political and economic crises that the apartheid government experienced from being unable to rule in the same old way, as it continued to impose states of emergencies and martial law, insinuated victory for the national liberation movement. The ANC emphasised the call on its mass base to make the country ungovernable and apartheid unworkable, as well as to further deepen the crises for the apartheid government. ${ }^{28}$ Moreover, with the defeat of the SADF by the joint Angolan and Cuban armed forces in the battle of Cuito Cuanavale, in southern Angola in July 1988, the apartheid government was compelled to negotiate a peaceful settlement of the Angolan war and to accept Namibian independence. ${ }^{29}$

"The battle itself was closely contested, but it was Pretoria that suffered the strategic defeat. It was forced to accept that it had lost control of the air to the superior Cuban Mig fighters; and that the increased loss of white

ANC National Executive Committee. Op cit. p 7.

Kasrils, Ronnie. Op cit. pp $6-7$.

Tambo, O.R. Op cit. p 2.

Castro, Fidel. (1988). "The Battle for Angola: Fidel Castro Speaks." SECHABA: Official Organ of the African National Congress South Africa. Nov 1988. pp 2-7. 
lives was politically unsustainable in defence of a territory that was remote for most South Africans." 30

With these conditions being accompanied by the "New Political Thinking in International Relations", introduced by the leader of the Soviet Union, Mikhail Gorbachev, which finally led to the demise of the Cold War, the apartheid government was ultimately forced by the leading powers in the Western hemisphere, through economic sanctions and boycotts, as well as intensifying diplomatic pressure to release all political prisoners, to legalise all political organisations, and to negotiate a peaceful settlement of the South African political question ${ }^{31}$.

\section{The ANC, the Armed Struggle, and a Negotiated Settlement}

The ANC, on the one hand, was unequivocal in its principle of not being opposed to a negotiated settlement for as long as the process was to ensure the attainment of a non-racial and democratic dispensation based on one-man-one-vote in a united South African state, thus guaranteeing the transfer of power to the people. $^{32}$

"We take the position that we want political power to be transferred to the democratic majority. This is the bottom line of our argument. We are saying that the question of democracy in a united South Africa is not negotiable. The second thing we are saying is power should be handed over to the democratic majority in our country. We are prepared to negotiate for the dismantling of apartheid and the transfer of power to the democratic majority." 33

On the other hand, preparations for People's War and Insurrection were not disbanded (under Operation Vula), since it was believed that the apartheid government was not genuine in its interpretation of a negotiated settlement. The objective was that if the racist government tried to renege on its position, then the return to the strategic objective of seizing power through insurrection should be intact and even more intensified as politico-military cadres of MK were infiltrated into the country in large numbers. ${ }^{34}$ Furthermore, cadres were sent to other states of the Non-aligned Movement in Asia, Latin America and the rest of Africa to receive

Barber, James. (2000). "South Africa's Political Miracle: The International Dimension." South African Journal of International Affairs. Vol. 7, No. 1. Summer. p 55 .

Ibid. pp $53-57$.

Mzala. (1989). "Negotiations and People's Power." SECHABA: Official Organ of the African National Congress South Africa. Aug 1989. pp $22-24$.

Hani, Chris. (1986). "25 Years of Armed Struggle: Army Commissar Chris Hani Speaks." SECHABA: Official Organ of the African National Congress South Africa. Dec 1986. p 14.

Mzala. Op cit. p 30. 
advanced conventional military training for the objective of becoming integrated into (or the establishment of) a prospective defence force of a new democratic South Africa. Therefore, negotiations were seen as a means towards an end, which if violated, the original programme of action, of arming the masses for people's war and insurrection, could be resorted to. "Insurrection", was defined by Ronnie Kasrils as "an open armed action taken by certain classes or social forces against the existing political power. It is the highest stage in the revolutionary process - the culmination of the objective and subjective factors at a decisive moment which, if the revolutionary forces are properly guided, leads to the seizure of power., ${ }^{35}$

It was also apparent to the ANC leadership and membership that negotiations were not going to lead to the consummation of the objectives of the national democratic revolution as envisaged in the Freedom Charter. Nelson Mandela emphasised that with negotiations "the struggle is not over, and negotiations themselves are a theatre of struggle, subject to advances and reverses as any other form of struggle". ${ }^{36}$ However, the position was that if negotiations could lead to the transfer of power to the people, then the transitional period, wherein power will be consolidated in favour of the revolutionary process, will ensure that certain objectives of the national democratic revolution are gratified.

\section{Absolute versus Relative Victories}

The main hindrances to the consummation of the objectives of the national democratic revolution were clearly identified as the transfer of wealth and land to the people, as well as the resistance that would be encountered with regard to the restructuring of the security forces. These three aspects constituted the core of apartheid's immovability in the process of negotiating a peaceful settlement. ${ }^{37}$ Nonetheless, the parties to the negotiations agreed to certain clauses that ensured that property rights will not be interfered with, and that there would be a gradual transfer of control of the armed and security forces. This was not the full realisation of the objectives of the national democratic revolution as visualised in the Freedom Charter. However, the ANC had prepared its following for the inevitable circumstances, that victories attained through negotiations are rarely absolute, judging from the experiences of other national democratic revolutions in the developing world. It was therefore emphasised that the focus of the revolutionary forces should be on the transfer of political power to the people, which, in the longrun, could be consolidated to include the sharing of the country's wealth and the transfer of land to those who would need to use it. These aspects had to be undertaken in succession within a continuous political process that will guarantee the irreversibility and the consolidation of the attained victories.

Kasrils, Ronnie. Op cit. p 9. 
For the cadres of MK the debate between absolute and relative victories was initially a disappointing affair after intensive and extensive preparations for people's war and the seizure of power through insurrection. Nevertheless, as politically- and military-groomed visionaries, MK cadres were geared to adapt to changes in the political situation regardless of the adverse consequences. This was due to the significance that was placed on the comprehension of the domestic and international political dynamics in all military training programmes, as well as the dearth of ambiguity in the principle of the primacy of politics over the armed struggle.

"The strategy and tactics of the ANC clearly state the superiority of the political leadership over the military. It cannot be otherwise for our military line stems from our political line. It is the political leadership that, because of its tasks and place of co-ordinating and directing all the activities of the movement, can more ably direct the military leadership and give it its strategic tasks. ... All military cadres of our movement are first and foremost politicians." 38

Furthermore, the negotiations for the integration of MK into the new South African National Defence Force (SANDF) was a relatively successful enterprise, albeit infested with difficulties arising from the resolute political experiences of all the fusing armed forces. 


\section{The Integration Process: The Need for Political Re-Orientation ${ }^{39}$}

Although the integration process was acknowledged globally to be a successful undertaking that could be emulated by other countries involved in internal and regional conflict resolution projects, past political differences and residues of racism and ethnicity, which are currently reflected in the entirety of South African society, were not pre-empted. It became apparent in the military training courses and in day-to-day interaction between the members of the various forces that wariness, underestimation, language discrimination, and animosity was still latently prevalent amongst the diverse racial, ethnic and ideological groups. These dormant feuds were made salient by spontaneous events of racial and ideological hatred, such as was experienced in Bloemfontein and Phalaborwa, as well as in the composition of the rank structure of the SANDF: with whites forming the majority of the officer corps, and blacks (Africans, so-called Coloureds and Indians) constituting the majority of the lower ranks.

In order to address these differences, the Minister of Defence appointed a Commission of Inquiry, which was still continuing with its investigation during the time of writing this article. Nevertheless, since all the armed forces that constitute the new SANDF have a solid political past, it will be appropriate to introduce a political education programme that would totally eradicate antecedent political thinking, which cannot be erased by any other means, besides perhaps financial and material incentives. The reason for this assertion is that, on the one hand, the tendencies of racial, ethnic or ideological discord are imbued in the attitudes of individuals who did not have an opportunity to review the changed political circumstances since the integration project was initiated. On the other hand, there was no programme that was introduced within training institutions to overcome these tendencies, both from the perspective of the tutors, instructors and mentors, as well as the from the viewpoint of the students and trainees.

In most instances, the tutors, instructors and mentors were the ex-SADF members, and the students and trainees were members of the former Non-Statutory Forces (NSF), and as such, within a military environment wherein strict obedience and discipline is demanded from the latter, uncalled-for antagonisms are inevitable. To a certain extent, these conditions became reminiscent of the apartheid period, since those responsible, the tutors, instructors and mentors, were not sensitised to the painful and bitter backgrounds that most former NSF members have gone through. These backgrounds included experiences of repression during mass actions, the difficulties of exile, imprisonment, and the death and suffering of some of their loved ones, such as families and friends. The most liable, who should have known better, are those who negotiated on behalf of the NSF members, who should have

The following sub-section is a comparison with the Idasa-ANC conference report on "The Future of Security and Defence in South Africa" held in Lusaka on the $23^{\text {rd }}$ to the $27^{\text {th }}$ of May 1990 reported by Cawthra, Gavin. (1990). "MK Tackles Future of the Military." SECHABA: Official Organ of the African National Congress South Africa. Aug 1990. pp 6-10. 
sensitised the other Statutory Forces, especially the former SADF, on the effects that indications of racism, ethnicity or other forms of discrimination might have on those who were victims of such tendencies in the past. Moreover, within the working environment, a similar arrangement was encountered, that also fortified these aversions.

A political programme to re-orient the thinking of all the members towards a non-racial and non-sexist SANDF, free of ideological or political inclinations, reflecting a democratic South African society, is an imperative, if not an exigency. Soldiers, sailors, airmen and military health operatives, have to consider themselves according to their calling regardless of their tint, language, or their previous political predilection, because these are the thorny issues adversely impacting on theesprit de corps of the members of the SANDF. It should not be pretended that these differences amongst members are non-existent, instead they should be openly discussed, ridiculed, be superannuated and discarded, rather than concealed. Once the members of the SANDF learn to live with the differences that exist amongst themselves and openly acknowledge them as part of their historical background, the more they will learn to accommodate their variances. This programme however cannot be sustained without concrete efforts towards redressing the composition of the rank structures through upgrading those who were disadvantaged by the past dispensations. Efforts towards this objective by the relevant directorates of the Department of Defence should be speeded up in order to ensure that transformation is perceptible to the majority of the people of this country, in particular the formerly disadvantaged sectors of South African society. The successes of the integration and transformation processes of the armed forces will be revealed in the manner in which the SANDF is cherished by the citizens of South Africa.

\section{Conclusions}

Ever since the ANC was formed, the focus of its activities was on the transfer of power to the people. This was the main initiator of the armed struggle in the early 1960s, when the racist government forbade all avenues for political participation. Armed struggle, therefore, relied on political dyna mics and direction for its execution, as well as depended on political developments internally and externally for its evolution and orientation. It was, therefore, not a goal or an end in itself, but a dependent pillar of the national democratic revolution. What is important to note, is that the armed struggle was, more than anything else, an instrument, a tool, to ensure the destruction of the inhuman apartheid system and the transfer of power to the people. Moreover, Umkhonto we Sizwe, as a revolutionary army, was not only created to develop the forces of revolution and for the seizure of power, Umkhonto was also contrived to defend and guarantee the gains of the national democratic revolution. ${ }^{40}$

On the one hand, in the process of the armed struggle, there were many sacrifices and injustices that were experienced by the participants, especially by MK 
cadres and their families. The atrocities that were perpetuated by the apartheid government in the townships and in the rural areas, as well as the bitter experiences of being in exile and in prisons, cannot be easily erased in the MK cadres' day-today interaction with society, especially with their former enemies. On the other hand, for all the diverse forces in the SANDF, new political attitudes need to be developed. Attitudes that will subdue the prevalent polarisation on racial, ethnic and ideological grounds, as this will not serve the building of a united and uniform force, which the country can be proud of as an epitome of an African military rena issance. Pretending that these differences within the South African armed forces do not exist will not achieve the desired results, and failing to redress the racial and ethnic imbalances within their rank structures will not guarantee the accomplishment of the integration and transformation processes. All these aspects should become open for deliberation within the South African armed forces and society at large so that the processes towards their resolution can be expedited. Condescending attitudes and discrimination in all its forms can still inadvertently reanimate the visions of the past, and thus render the armed forces impotent in terms of meeting their national obligations. It is therefore imperative that a political programme is adopted to overcome such potential protuberances. 